\title{
PENGARUH BRAND IMAGE DAN JALUR DISTRIBUSI TERHADAP KEPUTUSAN PEMBELIAN FASHION BRANDED MATAHARI (STUDI KASUS PADA CUSTOMER BASE ONLINE SHOP PRODUK MATAHARI HARGA GUDANG)
}

\author{
Haris Yuniarto'; M. Fadhli Nursal²; Rorim Panday3 \\ Fakultas Ekonomi Universitas Bhayangkara Jakarta Raya ${ }^{1,2,3}$ \\ haris.yuniarto@yahoo.com' fadhli@dsn.ubharajaya.ac.id² ${ }^{2}$ rorim.panday@yahoo.com³
}

ABSTRAK

Penelitian ini bertujuan untuk mengetahui seberapa besar Brand Image (X1) dan Jalur Distribusi (X2) terhadap Keputusan Pembelian (Y) fashion branded Matahari (studi kasus pada customer base online shop produk_matahari_harga_gudang. Penelitian ini merupakan penelitian kuantitatif dengan metode survey, dimana populasi pada penelitian ini adalah customer base online shop produk_matahari_harga_gudang yang berjumlah 112 orang dengan menggunakan teknik propotionate stratified random. Hasil perhitungan pada penelitian ini menggunakan program IBM SPSS 22. Hasil uji F menunjukan bahwa variabel Brand Image (X1) dan Jalur Distribusi (X2) berpengaruh secara simultan terhadap Keputusan Pembelian (Y) karena F hitung 45,221 lebih besar dari F tabel 1.68 dan signifikansi o,oo kurang dari 0,05. Sedangkan hasil Uji t menunjukan bahwa variabel Brand Image (X1) berpengaruh secara parsial karena didapatkan nilai t hitung sebesar 5,136 lebih besar dari t tabel 1,991 dan variabel Jalur Distribusi (X2) berpengaruh secara parsial karena didapatkan nilai t hutung 3,342 lebih dari t tabel 1,991 dan signifikansi 0,001 kurang dari 0,05. Sedangkan hasil hasil uji koefisien determinasi $\mathrm{R}$ square sebesar 0,453. Hal ini berarti 45,3\% intensitas Keputusan Pembelian dapat dijelaskan oleh variabel Brand Image dan Jalur Distribusi. Sedangkan sisanya yaitu 54,7\% intensitas Keputusan Pembelian dipengaruhi oleh variabel-variabel lainnya yang tidak diteliti dalam penelitian ini.

Kata Kunci : Brand Image,Jalur Distribusi dan Keputusan Pembelian.

THE INFLUENCE OF BRAND IMAGE AND DISTRIBUTION LINE ON THE PURCHASING DECISION OF MATAHARI FASHION BRANDED (CASE STUDY ON CUSTOMER BASE ONLINE SHOP PRODUCTS MATAHARI WITH PRICE WAREHOUSE)

This study aims to find out how big Brand Image (X1) and Distribution Channel (X2) for Purchase Decisions (Y) branded Matahari fashion (case study on customer base online shop produk_matahari_harga_gudang. This research is a quantitative research with survey method, where the population in this study 112 customer base online shop produk_matahari_harga_gudang using stratified random propotionate 
technique. The results of calculations in this study use the IBM SPSS 22 program. The $F$ test results show that the Brand Image (X1) and Distribution Channel (X2) variables simultaneously influence the Purchasing Decision (Y) because F count 45.221 more than F table 1.68 and significance 0.00 less than 0.05 . While the results of the test show that the variable Brand Image (X1) has a partial effect because the value of t count is 5.136 more than t table 1.991 and the path variable Distribution Channel (X2) has a partial effect because t value is hu tung 3.342 more than table 1.991 and significance 0.001 less than 0.05 . While the results of the test results of the determination coefficient $R$ square are 0.453 . This means that 45.3\% of the intensity of a Purchase Decision can be explained by the Brand Image and Distribution Path variables. Whereas the remaining 54.7\% intensity of Purchasing Decisions is influenced by other variables not examined in this study.

\section{Keywords: Brand Image, Distribution Channel, Purchasing Decision.}

Diterima: 15 Agust 2019; Direvisi: 16 Sept 2019; Diterbitkan: 30 Okt 2019

\section{PENDAHULUAN}

Industri ritel merupakan industri yang cukup strategis dalam kontribusinya terhadap perekonomian Indonesia. Indonesia tergolong cukup besar.Industri ritel memiliki kontribusi terbesar kedua terhadap pembentukan (GDP) setelah industri pengolahan. Selain itu, industri ritel juga memiliki peranan yang sangat penting bagi perekonomian Indonesia khususnya masyarakat Indonesia. Industri ritel menempatkan diri sebagai industri kedua tertinggi dalam penyerapan tenaga kerja Indonesia setelah industri pertanian. Hal ini mengindikasikan bahwa banyak orang menggantungkan hidupnya pada industri ritel.

Citra merek merupakan serangkaian asosiasi (persepsi) yang ada dalam benak konsumen terhadap suatu merek, biasanya terorganisasi menjadi suatu makna. Hubungan terhadap suatu merek akan semakin kuat jika didasarkan pada pengalaman dan mendapat banyak informasi. Citra atau asosiasi merepresentasikan persepsi yang bisa merefleksikan kenyataan yang objektif ataupun tidak.

\section{Menurut Kotler dan Amstrong (2012)} Brand Image merupakan seperangkat keyakinan konsumen mengenai merek tertentu. Kuatnya Brand Image di benak konsumen maka akan menyebabkan semakin kuat rasa percaya diri yang dirasakan oleh konsumen dalam menggunakan produk yang dibelinya. Rasa percaya diri yang tinggi ini menandakan bahwa konsumen tersebut merasa puas dengan produk yang dibelinya.(Gunawan \& Japarianto, 2017).

Pertumbuhan ritel di Indonesia yang sangat pesat memungkinkan semua perusahaan yang bergerak di bidang ritel membuat strategi yang baik untuk dapat menarik konsumen termasuk perusahaan Matahari Departemen Store. Fokus perusahaan ritel tidak hanya memusatkan perhatiannya pada penanganan pesaingnya, namun harus juga memperhatikan konsumen yang nantinya akan menentukan keberhasilan yang dijalankan oleh perusahaan ritel yang bersangkutan.

Banyak faktor yang mempengaruhi keputusan pembelian, diantaranya yang sering menjadi pertimbangan konsumen dalam memutuskan untuk membeli suatu produk adalah Brand Image atau Citra Merek dan juga 
harga produk itu sendiri. (T Hani Handoko, 1987:32).

Citra merek mempunyai peran penting untuk mencapai kepuasan dan loyalitas pelanggan. Menurut Stiadi dalam Sondakh (2014), citra terhadap suatu merek menjadi dasar pelanggan untuk melakukan keputusan pembelian. Dengan mempunyai citra merek yang baik maka para pelanggan dapat mengenali produk atau jasa yang dibelinya, mengetahui kualitas produk tesebut, dan memperoleh pengalaman dari produk tersebut, yang kemudian bisa merekomendasikan kepada orang lain. Penelitian Ogba dan Tan (2009), mengungkapkan ada efek positif dari citra merek pada keputusan pembelian.(Pelayanan, Citra, Yani, \& Surakarta, n.d.).

Brand fashion Matahari seperti Nevada, T-zone, St yves, Phenomenal, Aero, Little M, Arjuna Weda, dll. Merek lain sebagai kompetitornya seperti, Zoya, Old Navy, Zatta, H \& M, dll.

Selain itu citra merek yang perlu dipertimbangkan adalah saluran distribusi. Di Indonesia sendiri Matahari Departemen Store adalah perusahaan yang bergerak di bidang fashion yang cukup dikenal dan digemari oleh masyarakat Indonesia sendiri. Jika melihat pergerakan perusahaan retail eceran sekarang ini, Matahari mempunyai banyak kompetitor seperti Stars, Sogo, Ramayana dll. Maka diperlukan bauran promosi yang tepat agar tetap bisa bersaing atau mungkin top positioning daripada kompetitornya.

Bauran pemasaran mencakup segala hal yang bisa dilakukan perusahaan untuk mempengaruhi permintaan atas produknya. Bauran pemasaran terdiri dari 4 (empat) macam variabel yang dikenal dengan " $4 \mathrm{P}$ " yaitu : Produk (Product), Harga (Price), Promosi (Promotion), dan Tempat/Distribusi (Place). Dengan menerapkan bauran pemasaran, diyakini bahwa pemasaran akan memainkan peran penting dalam membangkitkan kegiatan ekonomi perusahaan dan akan meningkatkan standar mutu perusahaan.

\begin{abstract}
Saluran distribusi sering disebut "saluran perdagangan" atau "saluran pemasaran" dapat didefinisikan dalam beberapa cara, tetapi pada umumnya definisi yang ada memberikan gambaran tentang saluran distribusi ini sebagai rute/jalur.
\end{abstract}

Salah satu definisi saluran distribusi yang dikemukakan menurut Kotler dan Keller (2007:49) menyatakan bahwa : "Saluran pemasaran adalah organisasi-organisasi yang saling tergantung yang tercakup dalam proses yang membuat produk atau jasa menjadi tersedia untuk digunakan atau dikonsumsi”.(Agussalim \& Ali, 2017).

Yang tak kalah penting adalah saluran distribusi, dimana pendistribusian produk fashion Matahari harus bisa mencukupi kebutuhan fashion masyarakat kita, seperti contoh halnya di Bekasi sendiri terdapat 4 tempat Matahari Departemen Store padahal di daerah lain satu kotamadya berisi 5 kota dan kabupaten yaitu kotamadya Madiun hanya ada 1 Matahari Departemen Store dimana permintaan fashion di Madiun cukup tinggi.

Dari sekian banyak store yang menjadi pertanyaan adalah munculnya akun-akun sosial media yang menjual produk Matahari, baik di instagram, Facebook, dan sosial media lainnya. Ada beberapa daerah yang memang lingkupnya cukup luas hanya ada 1 Matahari saja dibandingkan dengan Bekasi kota yang tidak notabene terlalu luas namun terdapat 4 store Matahari, yaitu:

1. Matahari Metropolitan Mall

2. Matahari Revo Town

3. Matahari Grand Mall

4. Matahari Blu Plaza

Tujuan penelitian ini dilakukan adalah untuk mengetahui pengaruh Brand Image terhadap keputusan pembelian pembelian produk fashion Matahari pada customer base online shop produk matahari harga gudang, mengetahui pengaruh saluran distribusi terhadap keputusan pembelian pembelian produk fashion Matahari pada customer base online shop produk matahari harga gudang, dan mengetahui Pengaruh Brand Image dan saluran 
distribusi terhadap keputusan pembelian pembelian produk fashion Matahari pada customer base online shop produk matahari harga gudang.

\section{KAJIAN TEORETIK}

\section{Keputusan Pembelian}

Kehidupan manusia tidak lepas dari melakukan jual beli. Sebelum melakukan pembelian, seseorang biasanya melakukan keputusan pembelian terlebih dahulu terhadap suatu produk. Keputusan pembelian merupakan kegiatan individu yang secara langsung terlibat dalam pengambilan keputusan guna melakukan pembelian pada produk yang ditawarkan oleh penjual. Pengertian keputusan pembelian, menurut Kotler \& Amstrong (2001) adalah tahap dalam proses pengambilan keputusan pembeli di mana konsumen benar-benar membeli.

"Keputusan pembelian adalah suatu tahap dimana konsumen telah memiliki pilihan dan siap untuk melakukan pembelian atau pertukaran antara uang dan janji untuk membayar dengan hak kepemilikan atau penggunaan suatu barang atau jasa". Kotler (2005) juga menjelaskan yang dimaksud dengan keputusan pembelian adalah suatu proses penyelesaian masalah yang terdiri dari menganalisa atau pengenalan kebutuhan dan keinginan hingga perilaku setelah pembelian.

Menurut Peter dan Olson (2000) keputusan pembelian adalah proses mengkombinasikan pengetahuan untuk mengevaluasi dua atau lebih perilaku alternatif dan memilih salah satu diantaranya. "When you make a purchasing, consumers are faced with some choices of several existing products before deciding to make a purchasing. Furthermore, purchasing decision according to Schiffman, Kanuk (2004: 547) is "the election of two or more alternative purchasing decision, it means that someone can make a decision, it should be available some alternative options. So, the outlines is the decision to purchase can lead to how the process in the decision was made.
Furthermore, other references described by Peter and James (2004: 48) in Wibowo \& Karimah (2012: 6) the purchasing decision is the process by which consumers make the decision to purchase a variety of products and brands that began with the introduction of needs, information research, evaluation of information, making purchase and then evaluate the decision after purchasing.

Pre-purchase stage dimulai dengan munculnya perasaan membutuhkan (need arousal) dan kemudian mulai mencari informasi (information search) dan melakukan evaluasi dari alternatif (evaluation of alternatives) yang ada sebelum akhirnya membeli atau tidak membeli (buying decision) (Lovelock dan Wirtz, 2011, p60). Dalam fase ini pembeli mencari dan mempertimbangkan tentang produk atau service dan mulai membangun ekspektasi tentang produk atau jasa yang diinginkan.

Menurut Lovelock dan Wirzt (2011, p60) perasaan membutuhkan (need arousal)

a. Hal secara tidak sadar (unconscious minds) Lebih mengarah ke hal-hal yang tertanam dalam diri namun tidak disadari (identitas diri dan aspirasi adalah salah satu contoh).

b. Kondisi fisik (physical conditions)

Contohnya jika merasa lapar maka kita akan mencari makanan.

c. Sumber dari luar (external source)

Sumber dari luar yang dimaksud adalah stimulus dari luar. Contohnya jika kita melihat iklan dan kemudian ingin mencoba apa yang diiklankan

Kotler dan Keller (2009, p208) menyatakan bahwa adanya internal stimulus dan external stimulus yang menyebabkan terjadinya keinginan. Dengan adanya keinginan dari dalam diri (contoh: lapar) dan dipertemukan dengan stimulus dari luar (contoh: iklan restoran) maka terbentuklah tahapan pertama dari proses pengambilan keputusan. Pada saat perasaan membutuhkan disadari maka orang akan menjadi termotivasi untuk mencari informasi (Kotler dan Keller, 2009, p201-202; Lovelock dan Wirtz, 2011, p60).

\section{Peran Konsumen dalam Proses}




\section{Keputusan Pembelian}

Menurut Swastha dan Handoko (2011) berpendapat bahwa 5 peran individu dalam sebuah keputusan membeli, yaitu:

1. Pengambilan inisiatif (initiator): individu yang mempunyai inisiatif pembelian barang tertentu atau yang mempunyai kebutuhan atau keinginan tetapi tidak mempunyai wewenang untuk melakukan sendiri.

2. Iinfluencer atau orang yang mempengaruhi: individu yang mempengaruhi keputusan untuk membeli baik secara sengaja maupun tidak sengaja.

3. Pembuat keputusan (decider): individu yang memutuskan apakah akan membeli atau tidak, apa yang akan dibeli, bagaimana membelinya, kapan dan dimana membelinya.

4. Pembeli (buyer): individu yang melakukan pembelian yang sebenarnya.

5. Pemakai (user): individu yang menikmati atau memakai produk atau jasa yang dibeli

\section{Indikator Keputusan Pembelian}

(2016:194-201) :

Menurut pandangan Kotler dan Keller

1. Konsumen memiliki kebutuhan yang dapat dipenuhi oleh perusahaan

2. Konsumen mengumpulkan informasi mengenai kebutuhan yang dapat dipenuhi oleh perusahaan

3. Konsumen memilih perusahaan dibanding pesaing

4. Konsumen memutuskan membeli produk yang disediakan oleh perusahaan

5. Konsumen merasa puas setelah membeli produk perusahaan

\section{Brand Image}

Menurut Kotler (1998), citra merek adalah "seperangkat asosiasi, biasanya terstruktur dalam beberapa makna atau seperangkat keyakinan yang dimiliki tentang merek tertentu (Aaker, 1991). Kim (1990) mengemukakan bahwa "sebuah produk adalah hal fisik, "sebuah merek tidak memiliki sifat material, fisik, atau praktis; sejauh ini hanya nyata seperti produk. Membangun loyalitas merek terutama menyiratkan citra merek yang dapat dilakukan melalui media massa komunikasi dan juga kegiatan pemasaran jangka pendek seperti alat promosi juga bermanfaat untuk membentuk citra merek (Knox, 1996). Dalam konteks perbatasan, kita dapat mengatakan bahwa citra merek adalah caranya untuk mengetahui pandangan pelanggan tentang merek saat ini. Mengkomunikasikan citra merek ke target pelanggan adalah kegiatan pemasaran yang penting (Gardner dan Levy, 1955) karena dikomunikasikan dengan baik.

Kekuatan asosiasi merek ditentukan dari pengalaman langsung konsumen dengan merek, pesan-pesan yang sifatnya non komersial maupun yang sifatnya komersial.

1. Keunggulan asosiasi merek (favorability of brand association). Keunggulan asosiasi merek dapat membuat konsumen percaya bahwa atribut dan manfaat yang diberikan oleh suatu brand dapat memuaskan kebutuhan dan keinginan konsumen sehingga menciptakan sikap yang positif terhadap brand tersebut. Kekuatan asosiasi merek (strenght of brand association).

2. Kekuatan asosiasi merek (Strength of brand association) tergantung pada bagaimana informasi masuk dalam ingatan konsumen dan bagaimana informasi tersebut dikelola oleh data sensoris di otak sebagai bagian dari Brand Image. Ketika konsumen secara aktif memikirkan dan menguraikan arti informasi pada suatu produk atau jasa maka akan tercipta asosiasi yang semakin kuat pada ingatan konsumen.

Keunikan asosiasi merek (uniqueness of brand association) sebuah brand haruslah unik dan menarik sehingga produk tersebut memiliki ciri khas dan sulit untuk ditiru oleh para produsen.( Dwi Ajeng Wulandari ${ }^{1}$ 47-58). American Marketing Association yang dikutip dari (Kotler, 2009) mendefinisikan merek sebagai "nama, istilah, tanda, lambang, desain, atau kombinasinya,yang dimaksudkan untuk mengidentifikasikan barang atau jasa dari salah satu penjual atau kelompok penjual dan mendiferensiasikan mereka dari para pesaing. 
According to Kotler (1998), Brand Image is "a set of association, usually structured in some meaningful way" or the set of beliefs held about a particular brand (Aaker, 1991). Kim (1990) suggests that "a product is a physical thing," a brand has no material, physical, or practical properties; so far it is just as real as the product. Building brand loyalty mainly implies Brand Image that can be done through mass media communications and also short-term marketing activities such as promotional tools are also useful in order to shape a brand's image (Knox, 1996).

Menurut (Kotler, 2009) berpendapat bahwa merek juga menjalankan fungsi yang berhaga bagi perusahaan, yaitu:

1. Merek menyederhanakan pencarian suatu produk.

2. Merek membantu mengatur catatan persediaan dan pencatatan akuntansi.

3. Merek menandakan suatu kualitas tertentu sehingga pembeli yang puas akan melakukan pembelian ulang.

4. Merek menjadi suatu sarana yang kuat untuk mengamankan keunggulan kompetitif.

5. Merek juga memberikan perlindungan hukum kepada perusahaan untuk fitur-fitur atau aspek unik produk. Nama merek dapat dilindungi dengan melalui nama dagang terdaftar.

Salah satu hal yang memegang peranan penting dalam pemasaran adalah merek. Terdapat beberapa perbedaan antara produk dengan merek. Produk merupakan sesuatu yang dihasilkan oleh pabrik dan mudah ditiru oleh para pesaing. Sedangkan merek merupakan sesuatu yang dibeli oleh kosumen, memiliki nilai dan identitas atau ciri tertentu yang dilindungi secara hukum sehingga tidak dapat ditiru oleh pesaing. Merek mempengaruhi persepsi konsumen terhadap produk yang akan dibeli maka persaingan antar perusahaan adalah persaingan persepsi bukan produk (Tjiptono 2011;34).

\section{Komponen Pembentuk Brand Image}

Bagi perusahaan, merek merepresentasikan bagian ruang hukum yang sangat berharga dan dapat mempengaruhi perilaku konsumen, dapat dibeli ataupun dijual, dan memberikan keamanan pendapatan dimasa depan bagi pemiliknya. Citra merek selalu membantu pemasar untuk membangun posisi merek, dan untuk membedakan merek tersebut pesaing (Oxenfeldt dan Swann, 1964) dan efek ini juga meningkatkan kinerja merek di pasar (Shocker dan Srinivasan, 1979).

Tidak hanya praktisi periklanan (Oglivy, 1963) tetapi juga peneliti pemasaran (Gardner dan Levy, 1955) menunjukkan bahwa mendefinisikan citra merek dengan jelas dalam benak pelanggan adalah sumber vital keberhasilan pasar. Dalam tujuan jangka panjang, citra merek yang andal dan efisien berguna untuk membangun dan mempertahankan merek. Citra merek juga dapat menyediakan platform untuk perluasan merek yang ada (Park et al., 1991. Menurut (Aaker \& Biel, 1993), menyatakan bahwa citra merek terdiri dari tiga komponen, yaitu:

1. Citra Perusahaan (Corporate Image), yaitu sekumpulan asosiasi yang dipersepsikan terhadap perusahaan sebagai pembuat barang atau jasa.

2. Citra Produk (Product Image), yaitu sekumpulan asosiasi yang dipersepsikan konsumen terhadap suatu produk.

3. Citra Pemakai (User Image), yaitu sekumpulan asosiasi yang dipresepsikan konsumen terhadap pemakai yang menggunakan barang atau jasa.

Menurut Keller (2000) citra merek terdiri dari dua faktor utama yaitu:

1. Faktor fisik, merupakan karakteristik fisik dari merek yaitu: desain, kemasan, logo, nama merek, fungsi, dan kegunaan produk dari merek itu.

2. Faktor psikologis, dibentuk oleh emosi, kepercayaan, nilai dan kepribadian yang dianggap oleh konsumen dapat menggambarkan produk dari merek tersebut. Citra merek sangat erat kaitannya dengan apa yang orang pikirkan, rasakan terhadap suatu merek tertentu. Sehingga citra merek faktor psikologis lebih banyak berperan dibandingkan faktor fisik merek tertentu. 
Menurut Kotler (2002: 215 ), Brand Image adalah seperangkat keyakinan, ide, dan kesan yang dimiliki oleh seorang terhadap suatu merek. Karena itu sikap dan tindakan konsumen terhadap suatu merek sangat ditentukan oleh citra merek tersebut. Komponen Brand Image ada tiga, yaitu :

1. Citra Penjual (Corporate Image), yaitu sekumpulan asosiasi yang dipersepsikan konsumen terhadap perusahaan yang membuat suatu produkdan jasa.

2. Citra Pemakai (User Image), yaitu sekumpulan asosiasi yang dipersepsikan konsumen terhadap perusahaan yang membuat suatu produk dan jasa, meliputi pemakai itu sendiri, gaya hidup atau kepribadian dan status sosial.

3. Citra Produk (Product Image), yaitu sekumpulan asosiasi yang dipersepsikan konsumen terhadap suatu produk, meliputi atribut produk tersebut.

\section{Jalur Distribusi}

Menurut Philip Kotler (2007:112), jalur distribusi adalah suatu perangkat organisasi yang tergantung dan tercakup dalam proses yang membuat produk atau jasa menjadi untuk digunakan atau dikonsumsi oleh konsumen atau pengguna bisnis. Rico $\mathrm{R}$ Budidarmo menuliskan dalam bukunya (Pemasaran Strategic , 2009: 71) saluran distribusi kadangkadang disebut saluran perdagangan atau saluran pemasarandapat di definisikan dalam beberapa cara. Saluran distribusi ni digambarkan sebagai rute atau jalur yang dilalui oleh arus barang barang dari produsen ke perantara dan akhirnya sampai ke pemakai. Istilah barang sering diartikan sebagai bentuk fisik. Akibatnya definisi ini cenderung menggambarkan pemindahan barang dan jasa. Selai membatasi barang dan jasa yang disalurkan definisi ini juga membatassi lembaga-lembaga yang ada .( David A. Rezan).

Menurut Kismono (2001:367), saluran distribusi merupakan jalur atau keseluruhan perantara pemasaran yang dilalui barang dan jasa dari produsen ke pemakai industri dan konsumen, termasuk didalam transportasi dan pergudangan. Sebuah perusahaan harus pandai dalam melakukan penyebaran produknya.Perusahaan harus dapat melihat peluang pasar untuk mendistribusikan produknya, tidak hanya pasar lokal atau nasional tetapi juga internasional. Disamping itu perusahaan harus pandai dalam menentukan harga jual, khususnya dipasar internasional, karena perusahaan harus bekerja sama dengan cargo dan menggunakan biaya distribusi yang cukup mahal yang berdampak pada harga jual produk. Semua itu dilakukan agar produk perusahaan dapat dijangkau semua kalangan konsumen.(Djaharuddin, 2017).

\section{Faktor yang mempengaruhi saluran distribusi}

Dari beberapa faktor diatas menurut Riko R Budi Darmo dan kawan dapat diketahui adanya beberapa unsur penting dalam saluan distribusi, yaitu :

1. Pertimbangan Pasar merupakan jalur yang dipakai oleh produsen untuk memindahkan produk mereka melalui suatu lembaga yang mereka pilih.

2. Pertimbangan Barang kepemilikan produk baik secara langsung maupun tidak langsung dari produsen ke konsumen.

3. Pertimbangan Perusahaan bertujuan untuk mencapai pasar tertentu. Jadi pasar merupakan tujuan akhir dari kegiatan saluran.

4. Saluran Perantara merupakan suatu kesatuan dan melaksanakan sistem kegiatan (fungsi) yang lengkap dalam menyalurkan produk.

Menurut Yudhi Koesworodjati (2006:306), jalur distribusi adalah struktur unit organisasi antar perusahaan dan agen serta distributor, penjual grosiran dan eceran diluar perusahaan melalui sebuah komoditi, produk atau jasa dipasarkan. Ada beberapa faktor yang diperhatikan oleh perusahaan mengenai saluran distribusi menurut Keegan dalam Yudhi Koesworodjati (2006:309), diantaranya sebagai berikut :

1. Tempat yaitu ketersediaan produk atau jasa disuatu lokasi yang nyaman bagi pelanggan potensial. 
2. Waktu yaitu ketersediaan produk atau jasa yang diinginkan oleh seorang pelanggan (inventory).

3. Alur yaitu proses penyampaian produk dari produsen sampai ke konsumen.

4. Informasi yaitu jawaban atas pertanyaan dan komunikasi umum mengenai sifat - sifat produk yang berguna serta manfaat yang tersedia.

\section{Kerangka Berpikir dan Hipotesis}

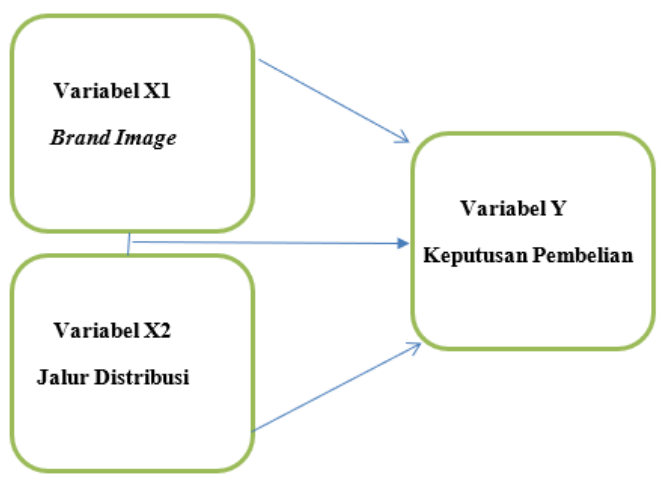

Gambar 2.

Kerangka Berpikir

\section{Metode Penelitian}

Metode penelitian dalam penelitian ini adalah metode penelitian kuantitatif dengan menggunakan analisis uji t, $\mathrm{F}$ dan multiple linear regression. Teknik pengumpulan data yang digunakan dalam penelitian ini adalah dengan metode survei. Pengumpulan data dilakukan dengan menggunakan kuesioner. Pengambilan sampel dilakukan secara stratified random sampling. Menurut Suryani Hendriyadi (2018) Stratified random sampling adalah teknik pengambilan sampel yang memberikan peluang yang sama bagi setiap unsur anggota populasi. Survei ini dilakukan terhadap responden yang online shop produk matahari harga gudang yang sudah berlangganan.

\section{HASIL PENELITIAN DAN} PEMBAHASAN
Tabel 1.

Responden Berdasarkan Alamat (Provinsi)

\begin{tabular}{|c|c|c|}
\hline No & Daerah & Jumlah responden \\
\hline 1 & Jawa Timur & 41 \\
\hline 2 & Jawa Tengah & 32 \\
\hline 3 & Jogja & 12 \\
\hline 4 & Jawa Barat & 14 \\
\hline 5 & $\begin{array}{c}\text { (Jakarta,Banten,dan luar } \\
\text { jawa) }\end{array}$ & 13 \\
\hline \multicolumn{3}{|c|}{ TOTAL SAMPEL } \\
\hline \multicolumn{2}{|c|}{ Sumber : Database online shop produk matahari harga gudang tahun 2019 }
\end{tabular}

Responden berdasarkan usia dalam penelitian ini yang memiliki jumlah terbanyak adalah yang berusia $26-35$ tahun yaitu sebanyak 62\%, jumlah kedua terbanyak adalah usia $15-25$ tahun yaitu sebanyak $26 \%$, jumlah terkecil adalah usia 36 - 45 tahun yaitu sebanyak $12 \%$.

Responden berdasarkan jenis kelamin terbanyak adalah perempuan yaitu sebanyak 81\% (91 responden) dam sisanya responden laki-laki sebanyak 19\% (21 responden). Jumlah responden perempuan jauh lebih banyak daripada laki-laki dengan selisih hampir $4 \mathrm{x}$ jumlah responden laki-laki

Responden berdasarkan waktu responden mengenal fashion brand Matahari yang terbanyak adalah responden mengenal brand Matahari >10 tahun sebanyak 38\% ( 42 responden ),5-10 tahun sebanyak 27\% ( 30 responden), 1 - 5 tahun sebanyak 22\% ( 25 responden), < 10 tahun sebanyak 13\% (15 responden). Ini membuktikan bahwa $87 \%$ (97) responden online shop produk matahari harga gudang mengenal branded Matahari > 1 tahun.

Responden berdasarkan sumber informasi responden mengenal fashion branded Matahari yang terbanyak adalah cari informasi sendiri atau mendatangi lokasi sebanyak 49\% (55 responden), dari teman sebanyak 21\% (24 responden), iklan sebanyak 12\% (13 responden), website sebanyak 9\% (10 responden) dan sisanya sumber lain sebanyak $9 \% \quad \%$ responden) 
Tabel 2.

Uji Validitas Barnd Image (X1)

\begin{tabular}{|c|c|c|c|}
\hline Korelasi antara & R hitung & R table & Kesimpulan \\
\hline Pernyataan 1 & 0.544 & 0.4444 & Valid \\
\hline Pernyataan 2 & 0.719 & 0.4444 & Valid \\
\hline Pernyataan 3 & 0.609 & 0.4444 & Valid \\
\hline Pernyataan 4 & 0.730 & 0.4444 & Valid \\
\hline Pernyataan 5 & 0.716 & 0.4444 & Valid \\
\hline \multicolumn{4}{|c|}{ Sumber-Data primer yang diolah, 2019 } \\
\hline
\end{tabular}

Tabel 3.

Uji Validitas Jalur Distribusi (X2)

\begin{tabular}{|c|c|c|c|}
\hline Korelasi antara & R hitung & R tabel & Kesimpulan \\
\hline Pernyataan 1 & 0.485 & 0.4444 & Valid \\
\hline Pernyataan 2 & 0.710 & 0.4444 & Valid \\
\hline Pernyataan 3 & 0.745 & 0.4444 & Valid \\
\hline Pernyataan 4 & 0.795 & 0.4444 & Valid \\
\hline Pernyataan 5 & 0.918 & 0.4444 & Valid \\
\hline Pernyataan 6 & 0.761 & 0.4444 & Valid \\
\hline Pernyataan 7 & 0.649 & 0.4444 & Valid \\
\hline & \multicolumn{4}{|c}{ Sumber-iData primer yang diolah, 2019 }
\end{tabular}

Tabel 4.

Uji Validitas Keputusan Pembelian (Y)

\begin{tabular}{|c|c|c|c|}
\hline Korelasi antara & R hitung & R table & Kesimpulan \\
\hline Pernyataan 1 & 0.755 & 0.4444 & Valid \\
\hline Pernyataan 2 & 0.896 & 0.4444 & Valid \\
\hline Pernyataan 3 & 0.738 & 0.4444 & Valid \\
\hline Pernyataan 4 & 0.826 & 0.4444 & Valid \\
\hline Pernyataan 5 & 0.901 & 0.4444 & Valid \\
\hline Pernyataan 6 & 0.873 & 0.4444 & Valid \\
\hline Pernyataan 7 & 0.631 & 0.4444 & Valid \\
\hline Pernyataan 8 & 0.828 & 0.4444 & Valid \\
\hline Pernyataan 9 & 0.896 & 0.4444 & Valid \\
\hline \multicolumn{5}{|c}{ Sumber Data primer yang diolah, 2019 } \\
\hline \multicolumn{5}{|l}{}
\end{tabular}

Tabel 5

Uji Reliabilitas X1, X2, dan Y

\begin{tabular}{|c|c|c|}
\hline & $\begin{array}{c}\text { Cronbach's } \\
\text { Alpha }\end{array}$ & No. Of Item \\
\hline $\mathrm{X} 1$ & 0,676 & 5 \\
\hline $\mathrm{X} 2$ & 0,829 & 7 \\
\hline $\mathrm{Y}$ & 0,931 & 9 \\
\hline
\end{tabular}

Hasil uji realibilitas dapat dilihat pada output Realibility Statistic. Didapat nilai
Cronbach's Alpha X1, X2 dan Y lebih besar dari o.6o. Maka hasil dari kuesioner yang disebar memiliki tingkat realibilitas yang baik, atau dengan kata lain data hasil kuesioner yang disebar dapat dipercaya.

Berdasarkan uji normalitas dengan Kolmogoriv Smirnov dan P Plot diperoleh berdistribusi normal.

Tabel 6.

Uji t

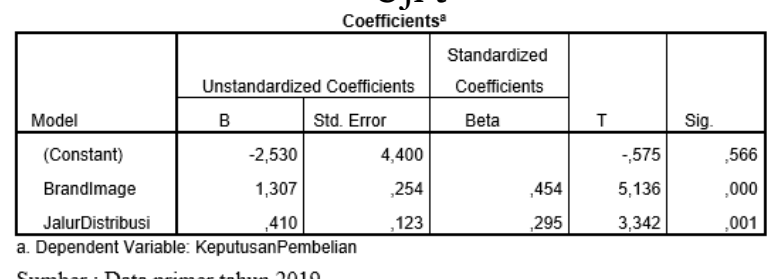

Sumber : Data primer tahun 2019

Berdasarkan hasil analisis dengan software SPSS diperoleh $\mathrm{t}$ hitung $(5,136)>\mathrm{t}$ tabel 1,991 berarti ada pengaruh brand image terhadap keputusan pembelian. Begitu pula sebaliknya diperoleh $t$ hitung $(3,342)>t$ tabel 1,991 berarti ada pengaruh jalur distribusi terhadap keputusan pembelian.

Tabel 7 .

Uji F

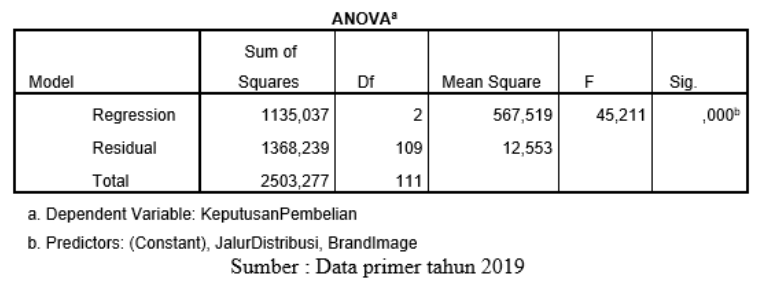

Berdasarkan hasil analisis dengan software SPSS diperoleh F hitung $(45,211)>$ F tabel 1,68 berarti ada pengaruh brand image dan jalur distribusi terhadap keputusan pembelian.

Tabel 8.

Uji Koefisien Determinasi

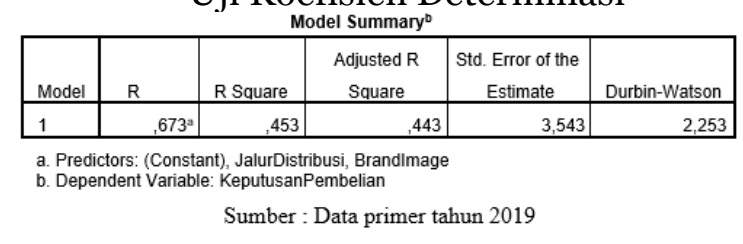

Dari hasil data tersebut dapat dilihat bahwa nilai koefisien determinasi atau R square 
sebesar 0.453 atau $45.3 \%$. Hal ini menunjukkan bahwa variabel yang diteliti (Brand Image) memberikan pengaruh terhadap keputusan pembelian sebesar $45.3 \%$, sedangkan $54.7 \%$ dipengaruhi variabel lain yang tidak diteliti.

\section{Pembahasan}

Penelitian ini dilakukan untuk memperoleh pemahaman yang lebih lengkap tentang pengaruh Brand Image dan jalur distribusi terhadap keputusan pembelian. Berikut ini akan disampaikan pembahasan hasil penelitian dengan mengacu kepada tujuan penelitian:

\section{Variabel Brand Image Terhadap Keputusan Pembelian}

Brand Image (Citra Merek) representasi dari keseluruhan persepsi terhadap merek dan dibentuk dari informasi dan pengalaman masa lalu terhadap merek itu. Dari hasil pengujian hipotesis secara parsial uji T variabel citra merek diperoleh nilai T-hitung sebesar 5,136 > 1,991 sedangkan statistik table ( $\mathrm{T}$ tabel) sebesar 1,991 dan nilai siginikansi variabel citra merek $0,00<$ dari 0,05. Sehingga dapat ditarik kesimpulan bahwa variabel bebas Brand Image secara parsial memiliki pengaruh positif dan relative signifikan terhadap keputusan pembelian.

Hasil penelitian ini mendukung hasil penelitian Wahyudin (2017). Terdapat pengaruh yang positif dan signifikan citra merek terhadap keputusan pembelian, artinya setiap peningkatan dan penurunan yang terjadi pada citra merek akan berdampak secara langsung pada keputusan pembelian. Citra merek berhubungan dengan sikap yang berupa keyakinan dan preferensi terhadap suatu merek. Konsumen yang memiliki citra yang positif terhadap suatu merek, akan lebih memungkinkan untuk melakukan pembelian.

Dengan demikian berdasarkan hasil penelitian yang penulis lakukan dimana nilai $t$ hitung lebih besar dibandingkan dengan t tabel dan nilai signifikansinya lebih kecil dari 0.05 hal ini berarti Ha diterima dan Ho ditolak sehingga hipotesis yang diajukan bahwa citra merek mempunyai pengaruh yang signifikan terhadap keputusan pembelian.

\section{Variabel Jalur Distribusi Terhadap Keputusan Pembelian}

Jalur disstribusi merupakan keseluruhan karakteristik dari proses penyampaian suatu produk yang menggambarkan skema produk sesuai yang diharapkan oleh pelanggan dalam memenuhi dan memuaskan keinginan pelanggan. Dari hasil pengujian hipotesis secara parsial uji $\mathrm{T}$ variabel jalur distribusi diperoleh nilai T-hitung sebesar 3,851 sedangkan statistik table (T tabel) sebesar 1,991 dan nilai siginikansi variabel kualitas produk 0,001 lebih kecil dari 0,05. Sehingga dapat ditarik kesimpulan bahwa variabel bebas jalur distribusi secara parsial memiliki pengaruh positif dan relative signifikan terhadap keputusan pembelian.

Hasil penelitian ini mendukung hasil penelitian wahyudin (2017). Terdapat pengaruh yang positif dan signifikan jalur distribusi terhadap keputusan pembelian.

Dengan demikian berdasarkan hasil penelitian yang penulis lakukan dimana nilai $\mathrm{T}$ hitung lebih besar dibandingkan dengan $\mathrm{T}$ tabel nilai signifikansinya lebih kecil dari 0.05 hal ini berarti Ha diterima dan Ho ditolak sehingga hipotesis yang diajukan bahwa jalur distribusi mempunyai pengaruh yang signifikan terhadap keputusan pembelian.

\section{Variabel Brand Image dan Jalur Distribusi terhadap Keputusan Pembelian}

Keputusan pembelian merupakan proses pembelian konsumen digambarkan melalui lima tahap aktivitas dimana konsumen mungkin melakukan pembelian barang dan jasa. Proses pembelian dimulai dengan pengenalan kebutuhan konsumen lalu berlanjut kepada tahap pencarian informasi, mengevaluasi pilihan alternatif, keputusan pembelian, dan yang terakhir evaluasi pasca-pembelian.

Berdasarkan hasil analisis data yang dalam penelitian ini diperoleh kesimpulan 
bahwa Brand Image dan jalur distribusi secara bersama-sama (simultan) berpengaruh terhadap keputusan pembelian. Hal tersebut dapat dilihat pada hasil uji F (simultan) dengan menggunakan SPSS versi 22 dimana nilai $F$ hitung 45,211 >F tabel 1,68 dengan nilai signifikansi lebih kecil dari 0.05 yaitu sebesar o,ooo. Karena memiliki signifikansi lebih kecil dari a $(0,05)$ yaitu sebesar o,ooo menunjukkan bahwa keputusan pembelian dapat dijelaskan oleh citra merek dan kualitas produk. Maka dapat disimpulkan bahwa variabel independen dalam penelitian ini secara bersama-sama (simultan) berpengaruh terhadap variabel dependen yaitu keputusan pembelian.

Hasil penelitian ini mendukung hasil penelitian Wahyudin (2017). Secara simultan terdapat pengaruh yang positif dan signifikan citra merek dan kualitas terhadap keputusan pembelian.

\section{KESIMPULAN}

1. Jika dilihat dari uji hipotesis dalam uji $\mathrm{t}$ diatas nilai $\mathrm{t}$ hitung 5,136 lebih besar dibanding dengan nilai t tabel 1,991 dengan signifikansi 0,00 kurang dari 0,05 dengan demikian $\mathrm{H}_{\mathrm{a}}$ diterima, artinya Brand Image memiliki efek secara parsial yang signifikan terhadap Keputusan Pembelian (Y).

2. Jika dilihat dari perhitungan secara parsial (uji t) jalur distribusi perhitungan bahwa nilai t hitung 3,342 lebih besar dari t tabel 1,991 dengan signifikasi o,001 kurang dari 0,05 yang berarti $\mathrm{H}_{\mathrm{a}}$ diterima, yang artinya variabel Jalur Distrbusi memiliki efek secara parsial terhadap Keputusan Pembelian (Y).

3. Terdapat efek yang saling berkaitan didalam uji f (simultan) di atas diperoleh nilai f hitung 45,21 lebih besar dari f tabel 1,68 yang artinya bahwa variabel bebas Brand Image (X1) dan Jalur Distribusi (X2) secara simultan memiliki efek yang saling berkaitan terhadap Keputusan Pembelian (Y). Kemudian diketahui nilai signifikansi kedua variable (0.00 \& 0,001) kurang dari 0,05, maka dapat disimpulkan Brand Image (X1) dan Jalur Distribusi (X2) secara simultan berpengaruh terhadap variabel Keputusan Pembelian (Y).

\section{SARAN}

1. Brand Image memiliki efek yang cukup tinggi terhadap keputusan pembelian fashion brand Matahari, semakin baik Brand Image terhadap produk fashion Matahari maka akan semakin besar konsumen melakukan keputusan pembelian.

2. Jalur distribusi memiliki peranan penting dalam keputusan pembelian, semakin baik proses penyampaian dan pendistribusian produk fashion Matahari kepada konsumen, maka semakin besar pengaruh terhadap konsumen dalam melakukan keputusan pembelian.

2. Hasil penelitian ini digunakan untuk mengetahui respon konsumen mengenai Brand Image dan jalur distribusi terhadap Keputusan Pembelian. Agar bisa meningkatkan penjualan dan profit pada online shop produk matahari harga gudang. Dari data yang sudah diuji maka online shop produk matahari harga gudang diharapkan mampu meningkatkan branding, kualitas, garansi dan segala aspek termasuk kecepatan respon,ketepatan waktu pengiriman dan aspek aspek lain guna mendapatkan keputusan pembelian yang berbanding lurus dengan penjualan.

\section{DAFTAR PUSTAKA}

Agussalim, Ali (2015). Model Kepuasan Pelanggan ; Analisis Kualitas Merek Produk dan Kuaalitas Layanan Terhadap Citra Merek Pada Giant Citra Raya Jakarta ; Jurnal Manajemen/vol XXI,No 3, Oktober $2017: 317-335$

Wikipedia, 2019. Daftar Matahari Se Jawa Bali, https://id.wikipedia.org/wiki/Matah ari Department Store) ; ( akses 5 Maret 2019

Dharmawanty Djaharudin , (2019); Pengaruh Saluran Distribusi Terhadap Volum Penjualan pada UD. Timur Terang Makassar.

Prafulla Pawar (2015), Assessment Of Brand Image And Brand Attachment 
Amongst Cell Phone Users : JIMS, Volume 15, Number 3,

Dwi Ajeng Wulandari,Farah Oktavani: (2017) . Pengaruh Brand Image Terhadap Proses Keputusan Pembelian Sepatu Nike (studi kasus Mahasiswa Fakultas Ekonomi dan Bisnis Telkom Universty Bandung ; Jurnal Computech \& Bisnis, Vol 11, No 1. Precess Of Problem Recognition : ///F:/BAB 4/uji referensi/bab 2/Bagan hawkins.html

Dudung Juhana: ( 2018 ) Pengaruh kualitas Produk Dan Promosi Terhadap Keputusan Pembelian ; Jurnal Ekonomi ,Bisnis dan Enterpenership, Vol 17 No 1

Bob Foster; 2016, Impact of Brand Image on Purchasing Decision on Mineral Water Product "Amidis" (Case Study on Bintang Trading Company) ,(ARJHSS) ISSN: 2378-7031 Volume 2, 2016, 11 pages

Rico R Budidarmo ; 2009, Pemasaran Strategik (Strategi Untuk Pertumbuhan Perusahaan Dalam Penciptaan Nilai Bagi Pemegang Saham) , Edisi Pertama, 2009: hal $71-76$

Rinaldo Adi \& Mira Silviani: Tahapan-Tahapan Penelitian Kualitatif Dan Kuantitatif ; file:///F:/BAB\%204/uji\%2oreferensi /bab\%203/tahapan\%2openelitian\%2 okuantitatif.html

Suryani,Hendriyadi, 2016 ; Jakarta, Fajar Intaprama Mandiri ; Metode Riset Kuantitatif , Cetakan Ke 2, 2016, hal 261 